\title{
ELAVL1 wt Allele
}

National Cancer Institute

\section{Source}

National Cancer Institute. ELAVL1 wt Allele. NCI Thesaurus. Code C107476.

Human ELAVL1 wild-type allele is located in the vicinity of 19p13.2 and is approximately $47 \mathrm{~kb}$ in length. This allele, which encodes ELAV-like protein 1, is involved in the regulation of mRNA stability. 